\title{
Sialoadhesin Binds Preferentially to Cells of the Granulocytic Lineage
}

\author{
Paul R. Crocker, ${ }^{*}$ Sylvie Freeman, ${ }^{*}$ Siamon Gordon, ${ }^{\star}$ and Sorge Kelm ${ }^{5}$ \\ *Imperial Cancer Research Fund Laboratories, University of Oxford, Institute of Molecular Medicine, John Radcliffe Hospital, Oxford \\ OX3 9DU, United Kingdom; ${ }^{\ddagger}$ Sir William Dunn School of Pathology, University of Oxford, Oxford, OX1 3RE, United Kingdom; and \\ ${ }^{8}$ Biochemisches Institut der Universität Kiel, 24098 Kiel, Germany
}

\begin{abstract}
Sialoadhesin is a macrophage-restricted, sialic acid-dependent receptor of $185 \mathrm{kD}$ that binds to the oligosaccharide sequence NeuAca2,3Gal on cell surface glycoconjugates. Recent cDNA cloning has shown that sialoadhesin is a new member of the immunoglobulin superfamily with sequence similarity to CD22, a sialic acid-dependent receptor of $B$ lymphocytes. Sialoadhesin has been implicated in cellular interactions of stromal macrophages with developing myeloid cells. In this study, direct evidence for this interaction was obtained in cell-cell binding assays using both native and recombinant forms of the protein. In all assays, sialoadhesin exhibited specific, differential binding to various murine cell populations of hemopoietic origin. In rank order, sialoadhesin bound neutrophils $>$ bone marrow cells = blood leukocytes $>$ lymphocytes $>$ thymocytes. Singlecell analyses confirmed that sialoadhesin selectively bound myeloid cells in complex cell mixtures obtained from the bone marrow and blood. In comparison, a recombinant Fcchimeric form of murine CD22 showed high binding to B and $\mathrm{T}$ lymphocytes, but very low binding to immature and mature myeloid cells. These results are consistent with the notion that sialoadhesin is involved in interactions with granulocytes at different stages of their life histories. ( $J$. Clin. Invest. 1995. 95:635-643.) Key words: hemopoiesis • neutrophils $\cdot$ inflammation $\cdot$ sialic acid $\cdot$ bone marrow
\end{abstract}

\section{Introduction}

Carbohydrate-binding proteins are important in a wide variety of biological processes involving specific cell-cell interactions. In mammals, the best characterized carbohydrate-binding proteins are the selectins, which are involved in leukocyte-endothelial cell interactions and contain a C-type lectin domain at the amino terminus (1).

Members of the immunoglobulin superfamily $(\mathrm{IgSF})^{1}$ me-

Address correspondence to Dr. Paul R. Crocker, ICRF Laboratories, University of Oxford, Institute of Molecular Medicine, John Radcliffe Hospital, Oxford OX9 3DU, United Kingdom. Phone: 865-222355; FAX: 865-222431; e mail: p_crocker @icrf.icnet.uk.

Received for publication 20 April 1994 and in revised form 28 October 1994.

1. Abbreviations used in this paper: $\mathrm{BM}$, bone marrow; IgSF, immunoglobulin superfamily; M $\phi$, macrophage(s); PBA, PBS + $0.25 \%$ BSA; RBC, red blood cell.

\section{J. Clin. Invest.}

(c) The American Society for Clinical Investigation, Inc.

0021-9738/95/02/0635/09 \$2.00

Volume 95, February 1995, 635-643 diate diverse recognition functions at the cell surface via both homotypic and heterotypic interactions. In general, these molecular interactions are considered to be protein-protein in nature, involving in each case a relatively restricted range of "ligand" counter receptors. Recently, however, it has become apparent that certain members of the IgSF can also function as lectinlike receptors by binding to specific carbohydrate determinants present on a potentially wide range of counter receptors (24 ). The best established of these is the human B cell-restricted antigen, CD22, which has seven Ig-like domains and can function as a sialic acid-dependent adhesion molecule $(4,5)$. Upon transient expression in monkey COS cells, human CD22 has been shown capable of binding $\mathrm{T}$ cells, $\mathrm{B}$ cells, monocytes, granulocytes, and erythrocytes (RBCs) in a sialic acid-dependent manner, via recognition of $\mathrm{NeuAc} \alpha 2,6 \mathrm{Gal} \beta 1,4 \mathrm{Glc}$ (NAc) in N-linked glycans on a wide range of cell surface glycoproteins $(6-8)$.

Sialoadhesin is a macrophage $(\mathrm{M} \phi)$-restricted plasma membrane receptor with an apparent $M_{\mathrm{r}}$ of $185 \mathrm{~K}$. It has been characterized as a sialic acid-binding protein that specifically recognizes the oligosaccharide sequences $\mathrm{NeuAc} \alpha 2,3 \mathrm{Gal} \beta 1,3-$ GalNAc and NeuAc $\alpha 2,3 \mathrm{Gal} \beta 1,3(4)$ GlcNAc in either glycoproteins or glycolipids $(9,10)$. Recent cDNA cloning has revealed that sialoadhesin is a new member of the IgSF (3). With 17 extracellular Ig-like domains, it is the largest cell surface member of this family so far described. Importantly, the first four amino-terminal Ig-like domains of sialoadhesin share $\sim 50 \%$ sequence similarity with a distinct subgroup of the IgSF that includes CD22. This establishes the fact that members of the IgSF can mediate cellular interactions through recognition of specific cell surface glycoconjugates (11).

The distribution and properties of sialoadhesin indicate that the receptor functions in vivo as a $\mathbf{M} \phi$-restricted cellular interaction molecule that binds appropriate sialylated ligands on developing myeloid cells in the bone marrow (BM) and lymphocyte subpopulations in lymphoid tissues $(12,13)$. To address directly the question of whether sialoadhesin can function as a cellular interaction molecule for granulocytic cells and other cells of hemopoietic origin, we have studied its binding properties in a range of binding assays with both native and recombinant forms of the receptor. We demonstrate that sialoadhesin can mediate differential, sialic acid-dependent binding to murine hemopoietic cells. Importantly, cells of the granulocytic lineage consistently show the highest levels of binding in all assay systems. The implications of these findings for the possible functions of sialoadhesin are discussed.

\section{Methods}

Materials. Unless specified otherwise, all reagents and chemicals were purchased from Sigma Chemical Co. (Poole, UK, or St. Louis, MO). Carrier-free $\mathrm{Na}^{125} \mathrm{I}$ and $\mathrm{Na}_{2}{ }^{51} \mathrm{CrO}_{4}$ were purchased from Amersham Int. (Slough, UK). Sialidase from Vibrio cholerae or Arthobacter ureafa- 
ciens and octylglucoside were purchased from Calbiochem-Behring Corp. (La Jolla, CA). Dextran T-500, Sephacryl S-300, and Percoll were obtained from Pharmacia Fine Chemicals Ltd. (Uppsala, Sweden). Dulbecco's modification of Eagle's medium and PBS without calcium and magnesium were purchased from Gibco Biocult Ltd. (Paisley, Scotland).

Animals. Specific pathogen-free male or female C57B1/6 mice were bred at the Pasteur Institute, the Sir William Dunn School of Pathology, or Clare Hall, ICRF, and used at 6-12 wk of age. Female AO rats at 8-16 wk of age were bred at the Sir William Dunn School of Pathology. Albino rabbits were provided by Oxford University Park Farm, Northmoor, UK.

Purification of sialoadhesin. Sialoadhesin was purified as described previously (9), with the following modifications: $2 \%$ CHAPS was used instead of sodium deoxycholate as the detergent, and the total spleen lysate was cleared of nuclei and insoluble material by centrifugation at $20,000 \mathrm{~g}$ for $30 \mathrm{~min}$. The yield of sialoadhesin was $\sim 700 \mu \mathrm{g}$ per 100 $\mathrm{g}$ of spleens, and purity was estimated at $95 \%$ by SDS-PAGE.

Antibodies. IgG, $\mathrm{F}\left(\mathrm{ab}^{\prime}\right)_{2}$, and Fab fragments of SER-4 (IgG2a), a rat $\mathrm{mAb}$ directed against sialoadhesin, were prepared as described previously (14). Purified IgGs from $5 \mathrm{C} 1$, a rat $\mathrm{IgG} 2 \mathrm{c}$ mAb against the murine $\mathrm{M} \phi$-restricted $\mathrm{F} 4 / 80$ antigen, and $5 \mathrm{C} 6$, a rat IgG2b against murine CD11a (15), were used as negative controls in some experiments. GK1.5 (anti-CD4), TIB 165 (anti-CD8), and TIB 146 (antiB220) rat mAbs were generously provided by Dr. J.M. Austyn (Oxford University, UK). NIMP-R14 rat anti-mouse neutrophil mAb (16) was a kind gift of Dr. C.J. Sanderson (University of Western Australia). The rat myeloma cell, Y3, was provided by Dr. C. Milstein (Cambridge University, UK).

To prepare a new panel of mAbs directed to different epitopes of sialoadhesin, an AO rat was immunized with purified sialoadhesin, using a regime described previously (14) except that the final injection was intrasplenic. Hybridoma supernatants were screened for their ability to block sheep RBC binding to mouse serum-induced peritoneal M $\phi$ (14). 10 stable hybridomas were cloned. Their designations and isotypes are as follows: 1C2 (IgG2a), 1C3 (IgG1), 2D5 (IgG1), 2F8 (IgG1), 3B3 (IgG1), 3B8 (IgG2a), 3D6 (IgG2a), 4D5 (IgG1), 4F7 (IgG1), and 5D8 (IgG1).

IgGs from the panel of mAbs were purified from ascites by sodium sulfate precipitation and FPLC ion exchange chromatography using a Mono-Q column. Fab and $\mathrm{F}\left(\mathrm{ab}^{\prime}\right)_{2}$ fragments were prepared as described previously for SER-4 (14), except that FPLC Mono-Q ion exchange chromatography was used instead of DEAE-Sephacel.

A rabbit polyclonal anti-sialoadhesin antiserum (R6.2-4) was prepared by immunization of an albino rabbit with purified sialoadhesin. IgG was purified from the pooled serum by chromatography on protein A-Sepharose, and Fab and $F\left(a b^{\prime}\right)_{2}$ fragments were prepared by standard methods.

The purities of IgGs and fragments were consistently $>95 \%$, as assessed by Coomassie blue-stained SDS-PAGE gels. Protein concentrations were determined by measuring absorbance at $280 \mathrm{~nm}$, assuming an extinction coefficient of 1.4

Epitope mapping. Thioglycollate-elicited peritoneal $\mathrm{M} \phi$ induced to express sialoadhesin were used as targets for epitope mapping (14). Cells were fixed in methanol for $10 \mathrm{~min}$ immediately before the binding assay, and nonspecific sites were blocked in PBS + 1\% BSA for 60 min at $37^{\circ} \mathrm{C}$. mAbs were iodinated by the Iodogen method to specific activities of $\sim 250 \mathrm{~Bq} / \mathrm{ng}$. Fixed $\mathrm{M} \phi$ were preincubated for $60 \mathrm{~min}$ with unlabeled $\mathrm{mAb}$ at $20 \mu \mathrm{g} / \mathrm{ml}$, and ${ }^{125}$ I-labeled mAbs were added to the wells at a final concentration of $72 \mathrm{kBq} / \mathrm{ml}(\sim 0.3 \mu \mathrm{g} / \mathrm{ml})$, in the continued presence of the unlabeled $\mathrm{mAb}$. After $60 \mathrm{~min}$ at room temperature, wells were rinsed five times with PBS $+0.1 \% \mathrm{BSA}$, and the bound radioactivity was solubilized by addition of $0.1 \mathrm{~N} \mathrm{NaOH}$ and counted in a Berthold gamma counter.

Preparation of cells. Human RBCs (type A or AB) were prepared fresh from the same donors and stored in Alsever's solution. Sheep erythrocytes were purchased from Gibco Biocult Ltd. and used within $2 \mathrm{wk}$. Sialidase treatment of cells was performed as described previously
(9). Resident peritoneal M $\phi$ were obtained as described (17). Mouse BM cells were flushed from excised femora and dissociated into a singlecell suspension by gentle pipetting in PBS followed by passage through a 25-gauge needle. Mesenteric lymph node cells and thymocytes were obtained by gentle dissociation of each tissue in PBS. Inflammatory neutrophils were obtained 18-24 h after subcutaneous injection of 1.5 $\mathrm{ml}$ of Bio-Gel P4 bead slurry, as previously described for $\mathbf{M} \phi$ with Bio-Gel P-100 beads (18). This resulted in a population of cells (P4 neutrophils) that consisted of $85-95 \%$ neutrophils and 5-15\% $\mathrm{M \phi}$, as assessed by May-Grünwald-Giemsa staining. Blood leukocytes were isolated from heparinized whole mouse blood by mixing 1:4 ( $\mathrm{vol} / \mathrm{vol}$ ) with $1.5 \%$ Dextran T-500 in PBS and allowing RBCs to sediment for $45 \mathrm{~min}$ at room temperature. Residual RBCs were lysed in $10 \mathrm{mM}$ Trisbuffered $0.85 \%$ ammonium chloride, $\mathrm{pH}$ 8.0. Enrichment of neutrophils from total blood leukocytes was performed on Percoll step gradients, using $2 \mathrm{ml}$ of each of the following densities $(\mathrm{g} / \mathrm{ml})$ in each $15-\mathrm{ml}$ tube: $1.10,1.095,1.09,1.085,1.08,1.075$. Leukocytes were loaded onto each Percoll gradient $\left(2 \times 10^{7}\right.$ per gradient $)$ and centrifuged at $950 \mathrm{~g}$ for $30 \mathrm{~min}$ at $15^{\circ} \mathrm{C}$. Cells at the interfaces were collected and pooled for each density step and washed three times in PBS prior to binding assays. The percentage of neutrophils in each fraction was determined from cytocentrifuge smears stained with May-Grüwald-Giemsa.

Radiobinding assays with native ${ }^{125} I$-sialoadhesin. Native sialoadhesin was iodinated as described previously (9) to give specific activities ranging from 30 to $120 \mathrm{~Bq} / \mathrm{fmol}$. Binding activity was retained when the purified iodinated receptor was diluted into PBS containing BSA in the absence of detergent. This meant that binding assays could be performed in the presence of negligible $(<0.01 \%)$ concentrations of CHAPS. The specificity of binding was assessed in all experiments by a 60 -min preincubation of ${ }^{125}$ I-sialoadhesin with $3 D 6 F\left(a b^{\prime}\right)_{2}$ fragments at $20 \mu \mathrm{g} / \mathrm{ml}$, or in some cases, by sialidase treatment of the cells. In some experiments, cells were fixed in $0.25 \%$ glutardialdehyde for 10 $\mathrm{min}$ at room temperature, washed, and quenched in PBS + $1 \%$ BSA for at least $60 \mathrm{~min}$ prior to binding assays. Cells were suspended at 2 $\times 10^{6} / \mathrm{ml}$ in PBS $+1 \%$ BSA, and $25 \mu$ l containing $5 \times 10^{4}$ cells was added to replicate wells of 96 -well microtiter plates. $25 \mu \mathrm{l}$ of ${ }^{125} \mathrm{I}$ sialoadhesin, preneutralized or not with 3D6 $\mathrm{F}\left(\mathrm{ab}^{\prime}\right)_{2}$, was added to each well and mixed. The plates were incubated for $60 \mathrm{~min}$ at $4^{\circ} \mathrm{C}$ for live cells or at room temperature for fixed cells and washed five times with $200 \mu$ l of PBS $+0.25 \%$ BSA (PBA) by centrifugation in plate carriers at $300 \mathrm{~g}$ for $2 \mathrm{~min}$ at room temperature.

Production of $\mathrm{Fc}$-adhesins. cDNAs encoding full-length sialoadhesin and murine CD22 were cloned into pcDNA I/Amp as described $(3,11)$. To produce $\mathrm{Fc}$-adhesins, cDNA fragments encoding four ( sialoadhesin) or three (CD22) extracellular domains were generated by PCR from the full-length cDNAs, cloned into the pIG vector, expressed in COS cells, and purified on protein A-Sepharose as described $(11,19)$ cDNA encoding human Fc-NCAM in pIG was kindly provided by Dr. D. Simmons (Oxford University, UK). This protein was used as a negative control in solid-phase binding assays.

Fluid-phase binding assays with complexed Fc-adhesins. To increase the valency of the dimeric Fc-adhesins, soluble complexes were formed using goat anti-human IgG (Fc specific) (Sigma Chemical Co.). ${ }^{125} \mathrm{I}$-Fc-adhesins were labeled as described (9) to specific activities of $40-60 \mathrm{~Bq} / \mathrm{fmol}$, diluted to $0.4 \mu \mathrm{g} / \mathrm{ml}$ in PBA, and preincubated with an equimolar concentration of anti-human IgG for $60 \mathrm{~min}$ at room temperature. ${ }^{125} \mathrm{I}-\mathrm{Fc}$-adhesin-IgG complexes were then incubated with $25 \mu$ l of a glutardialdehyde-fixed cell suspension $\left(1.5 \times 10^{5}\right.$ cells $)$ for $60 \mathrm{~min}$ at room temperature, the cells were washed in PBA, and the cell-associated radioactivity was counted. The sialic acid dependence of binding was determined by using sialidase-treated cells. Data shown are mean values of triplicate measurements.

Solid-phase binding assays with $F c$-adhesins. $\mathrm{Fc}$-adhesins at varying concentrations were adsorbed for $3 \mathrm{~h}$ at $37^{\circ} \mathrm{C}$ to wells of microtite plates that had been coated overnight at $4^{\circ} \mathrm{C}$ with goat anti-human IgG at $15 \mu \mathrm{g} / \mathrm{ml}$ in $0.1 \mathrm{M}$ bicarbonate buffer, $\mathrm{pH}$ 9.6. For quantitative binding assays, cells were washed three times in RPMI-1640 + $20 \mathrm{mM}$ Hepes, incubated for $60 \mathrm{~min}$ at $37^{\circ} \mathrm{C}$ with $100 \mu \mathrm{Ci}$ of ${ }^{51} \mathrm{Cr}$ per $10^{6}$ cells, and 
washed three times in PBA. Cells were adjusted to $8 \times 10^{6}$ cells per $\mathrm{ml}$ in PBA containing $5 \mathrm{mM}$ EDTA and $5 \mathrm{mM}$ sodium azide, and 50$\mu \mathrm{l}$ aliquots were added to wells of the microtiter plate containing $50 \mu \mathrm{l}$ of the same buffer. After $30 \mathrm{~min}$ at room temperature, the nonadherent and loosely adherent cells were removed with three washes. For the single-cell, qualitative binding assays, the same conditions were used, except that the ${ }^{51} \mathrm{Cr}$ labeling step was omitted and the adherent cells were fixed at the end of the assay prior to immunocytochemistry. The specificity of binding to $\mathrm{Fc}$-sialoadhesin was assessed in all experiments by a 60 -min preincubation of coated wells with SER-4 and 3D6 F $\left(\mathrm{ab}^{\prime}\right)_{2}$ fragments, each at $20 \mu \mathrm{g} / \mathrm{ml}$. Nonspecific binding was also assessed using Fc-NCAM-coated wells.

COS cell binding assays. COS cells were transfected with plasmids encoding full-length sialoadhesin using DEAE-dextran (19). Binding assays were performed with BM cells as described (3). The cells were fixed for $10 \mathrm{~min}$ in $0.25 \%$ glutardialdehyde in PBS prior to immunoperoxidase or Giemsa staining.

Cell binding assays to sialoadhesin expressed by $M \phi$. Resident peritoneal M $\phi$ were cultured for 3-5 d in RPMI-1640 containing $15 \%$ mouse serum, and binding assays were performed as described previously (20). To control for non-sialoadhesin-mediated binding, replicate wells were incubated in the same buffer containing $3 \mathrm{D} 6 \mathrm{~F}\left(\mathrm{ab}^{\prime}\right)_{2}$ at $20 \mu \mathrm{g} / \mathrm{ml}$ for $15 \mathrm{~min}$ prior to addition of cells. Unbound cells were removed by washing, and the cells were fixed in $0.25 \%$ ( $\mathrm{vol} / \mathrm{vol}$ ) glutardialdehyde. The percentage of M $\phi$ that formed rosettes ( $>4$ RBCs or $>1$ nucleated cell bound) or the number of cells bound per $100 \mathrm{M} \phi$ were determined by scoring at least $200 \mathrm{M} \phi$ per coverslip from triplicate coverslips using phase-contrast microscopy.

Single-cell analysis and immunocytochemistry. Cytocentrifuge preparations were fixed in acetone. Cells that had adhered specifically to Fc-adhesins in solid-phase assays on 96-well plates were fixed in a 1:1 mixture of acetone and methanol. Detection of cell surface antigens was then performed by immunoperoxidase labeling using a streptavidinbiotin-peroxidase kit (Vectastain; Vector Laboratories, Petersborough, UK). At least 200 cells were counted in each preparation.

\section{Results}

Characterization of $m A$ bs against sialoadhesin. To characterize the binding of sialoadhesin to hemopoietic cells, it was important to use blocking anti-sialoadhesin mAbs in the form of Fab or $\mathrm{F}\left(\mathrm{ab}^{\prime}\right)_{2}$ fragments since hemopoietic cells express $\mathrm{Fc}$ receptors that could interact with intact mAbs. Previously it was shown that SER-4, the original mAb raised to sialoadhesin, inhibited binding of sheep RBCs as IgG but not as Fab fragments and only partially as $\mathrm{F}\left(\mathrm{ab}^{\prime}\right)_{2}$ fragments (14). 10 new mAbs against sialoadhesin were selected by their ability to inhibit sheep RBC binding to induced peritoneal $\mathbf{M} \phi$. All mAbs bound specifically to purified sialoadhesin in dot blot assays and stained discrete $\mathbf{M} \phi$ populations in spleen and lymph nodes by immunocytochemistry, as described previously (14).

Epitope mapping. To determine whether different epitopes on the sialoadhesin molecule could be defined by the panel of mAbs, competition binding assays were performed using fixed M $\phi$ as targets (Table I). The majority of mAbs competed with SER-4 and therefore recognized the same epitope (epitope A). mAbs 3D6 and 1C2 defined a second, distinct epitope (epitope B), and 2F8 bound to a third epitope (epitope C) that seemed to overlap partially with that recognized by SER- 4 but none of the other mAbs.

Inhibition of purified sialoadhesin binding by the $m A b$ panel. The mAbs were next tested for their ability to inhibit binding of purified, iodinated sialoadhesin in cell binding assays. Purification of sialoadhesin in CHAPS results in oligomeric preparations of the receptor with a hemagglutinating ac-
Table I. Epitope Mapping on Sialoadhesin by Competition Binding Assay of Iodinated mAbs to Induced Peritoneal M $\phi$

\begin{tabular}{cccc}
\hline & \multicolumn{3}{c}{${ }^{125}{ }^{1-l a b e l e d ~ m A b^{*}}$} \\
\cline { 2 - 4 } Competing antibody $^{\ddagger}$ & SER-4 & 3D6 & 2F8 \\
\hline SER-4 & +++ & - & + \\
1C2 & - & +++ & - \\
1C3 & +++ & - & - \\
2D5 & +++ & - & - \\
2F8 & + & - & +++ \\
3B3 & +++ & - & - \\
3B8 & +++ & - & - \\
3D6 & - & +++ & - \\
4D5 & +++ & - & - \\
4F7 & +++ & - & - \\
5D8 & +++ & - &
\end{tabular}

$(+++)$ Complete competition ( $>95 \%$ inhibition); $(+)$ partial inhibition (40-60\% inhibition); ( - ) No competition ( $<10 \%$ inhibition). * MAbs were labeled with ${ }^{125} \mathrm{I}$ to specific activities of $\sim 260 \mathrm{~Bq} / \mathrm{ng}$ and added directly to the methanol-fixed $\mathbf{M} \phi$ at a final concentration of $\sim 300 \mathrm{ng} /$ $\mathrm{ml}$. Bound ${ }^{125} \mathrm{I}$-labeled $\mathrm{mAb}$ was estimated as described in Methods.

${ }^{\ddagger}$ Competing mAbs were added to $\mathrm{M} \phi$ at $20 \mu \mathrm{g} / \mathrm{ml}$ and incubated for 1 $\mathrm{h}$ before addition of ${ }^{125} \mathrm{I}-\mathrm{mAb}$.

tivity similar to that described previously for octylglucoside (9). Human RBCs were used in initial experiments, since they were shown previously to be excellent ligands for sialoadhesin (9) and do not express Fc receptors that could interfere with the assay. 3D6 and 1C2 IgGs showed complete inhibition of ${ }^{125}$ I-sialoadhesin binding at antibody concentrations as low as $0.1 \mu \mathrm{g} / \mathrm{ml}$ (Fig. $1 a$ ). Only partial inhibition was observed with the other anti-sialoadhesin antibodies, even at concentrations as high as $10 \mu \mathrm{g} / \mathrm{ml}$. This contrasts with their ability to inhibit completely binding of human RBCs to sialoadhesin expressed by $M \phi$, suggesting that the blocking in cell-cell binding assays is due to the effects of steric hindrance. Fab fragments prepared from $1 \mathrm{C} 2$ and $3 \mathrm{D} 6$ as well as $\mathrm{F}\left(\mathrm{ab}^{\prime}\right)_{2}$ from 3D6 were totally inhibitory for binding of sialoadhesin to RBCs, whereas SER$4 \mathrm{~F}\left(\mathrm{ab}^{\prime}\right)_{2}$ and $\mathrm{Fab}$ fragments or Fab fragments from normal rat serum IgG had little or no effect (Fig. $1 b$, Table II, and data not shown).

Taken together, these results demonstrate that 1C2 and 3D6 recognize an epitope that is closer to the binding site of sialoadhesin than that recognized by SER- 4 and the other mAbs. 3D6 $\mathrm{F}\left(\mathrm{ab}^{\prime}\right)_{2}$ fragments were used in additional studies as specific inhibitors of sialoadhesin binding.

Characteristics of ${ }^{125}$ I-sialoadhesin binding to murine BM cells. Binding assays were performed with murine BM cells and purified native ${ }^{125} \mathrm{I}$-sialoadhesin to determine whether these cells carried appropriate sialylated ligands (Table II). Similarly to human RBCs, sialoadhesin binding to BM cells was largely sialic acid dependent (Table II) and inhibited strongly by Fab fragments of 3D6 and 1C2. Inhibition by Fab fragments of SER4 was only partial (Table II). Since the binding of sialoadhesin to carbohydrate structures on cells was resistant to glutardialdehyde fixation (Table II), cells could be prepared in advance of binding assays.

Comparison of different murine cell populations for binding to ${ }^{125}$ I-sialoadhesin. It was important to determine whether the 


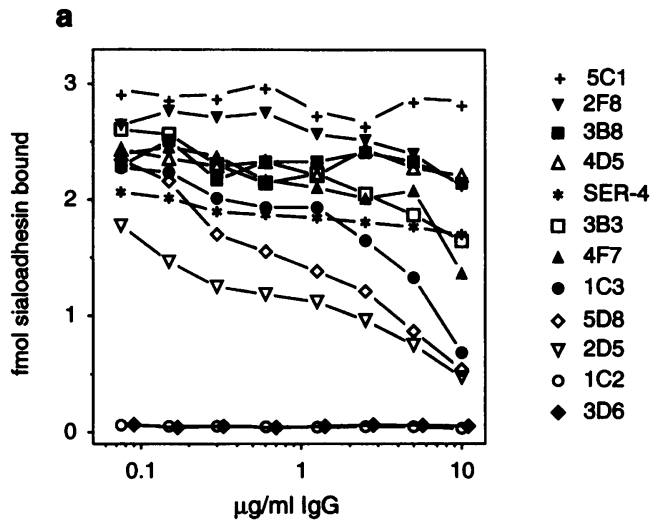

b

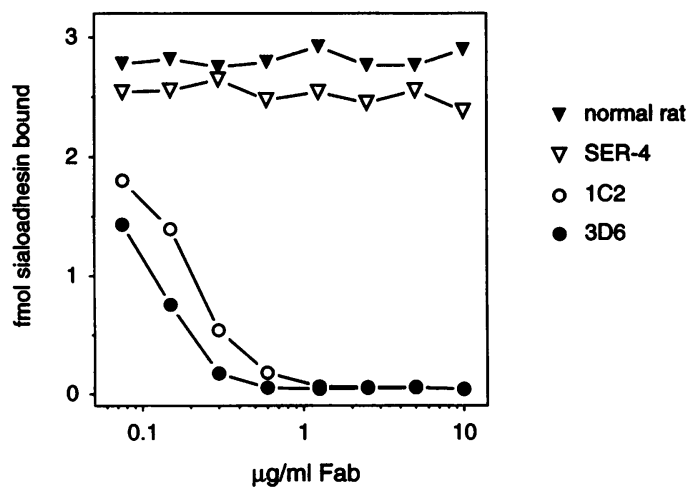

Figure 1. Inhibition of purified sialoadhesin binding to human RBCs by IgGs $(a)$ or Fab fragments $(b)$, purified from the panel of antisialoadhesin mAbs. 31-fmol aliquots of ${ }^{125} \mathrm{I}$-sialoadhesin at a specific activity of $100 \mathrm{~Bq} / \mathrm{fmol}$ were incubated for $60 \mathrm{~min}$ at room temperature with serial dilutions of the different mAbs. Human RBCs were added at $0.25 \%$ final concentration, and after $60 \mathrm{~min}$ at room temperature, they were washed and ${ }^{125} \mathrm{I}$-sialoadhesin binding was determined. The negative control in $a$ was $5 \mathrm{Cl}$, a mAb of the IgG2c subclass that binds to the murine $\mathrm{M} \phi$ antigen $\mathrm{F} 4 / 80$. The negative control in $b$ was Fab fragments purified from normal rat serum. Data show values from single wells at each concentration.

receptor could discriminate between different murine hemopoietic cell types in vitro, since this would favor the possibility that sialoadhesin is able to mediate selective cellular interactions in vivo. Initially, BM cell binding to sialoadhesin was compared with inflammatory neutrophils recruited to the site of Bio-Gel P4 injection, mesenteric lymph node cells, and thymocytes (Fig. $2 a$ ). For all cell types, binding was $>90 \%$ inhibitable by 3D6 and, where studied, by pretreatment of the cells with $V$. cholerae sialidase (data not shown). Unexpectedly, inflammatory neutrophils showed the highest level of binding, being approximately twofold higher than BM cells, fourfold higher than lymphocytes, and fivefold higher than thymocytes (Fig. $2 a$ ).

The high binding observed with inflammatory neutrophils raised the possibility that normal, circulating neutrophils are strongly recognized by sialoadhesin. Alternatively, neutrophil activation during recruitment could result in high levels of binding due to increased surface expression of ligands. To distinguish between these two possibilities, neutrophils were enriched
Table II. Characteristics of ${ }^{125}$ I-Sialoadhesin Binding to Murine $B M$ Cells Compared with Human RBCs

\begin{tabular}{|c|c|c|c|c|}
\hline \multirow[b]{3}{*}{ Treatment } & \multicolumn{4}{|c|}{ Femtomoles of sialoadhesin bound } \\
\hline & \multicolumn{2}{|c|}{ Human RBC } & \multicolumn{2}{|c|}{ Murine BM cells } \\
\hline & - & $+3 \mathrm{D} 6 *$ & - & $+3 \mathrm{D}^{*} *$ \\
\hline \multicolumn{5}{|l|}{ Experiment $1^{\ddagger}$} \\
\hline Control & 16.39 & 0.03 & 6.90 & 0.53 \\
\hline Sialidase (V. cholerae) & 0.15 & 0.09 & 1.85 & 0.73 \\
\hline Sialidase (A. ureafaciens) & ND & ND & 2.20 & 0.94 \\
\hline \multicolumn{5}{|l|}{ Experiment $2^{8}$} \\
\hline Control & 13.93 & 0.17 & ND & ND \\
\hline 5 mM EDTA & 15.99 & 0.17 & ND & ND \\
\hline \multicolumn{5}{|l|}{ Experiment $3^{\|}$} \\
\hline Control & 15.43 & 0.16 & 8.82 & 0.57 \\
\hline $0.25 \%$ Glutardialdehyde & 16.88 & 0.99 & 8.68 & 0.90 \\
\hline \multicolumn{5}{|l|}{ Experiment $4^{1}$} \\
\hline Control & 2.28 & 0.03 & 2.13 & 0.40 \\
\hline $1 \mathrm{C} 2 \mathrm{Fab}$ & 0.03 & ND & 0.36 & ND \\
\hline 3D6 Fab & 0.06 & ND & 0.35 & ND \\
\hline SER-4 Fab & 1.67 & ND & 1.20 & ND \\
\hline Normal rat Fab & 2.30 & ND & 2.09 & ND \\
\hline
\end{tabular}

Data show mean values of three to four replicates. Standard deviations are not shown for clarity but were consistently within $10 \%$ of the mean Binding assays were performed in $50 \mu \mathrm{l}$ with human RBCs at $0.25 \%$ final concentration or $5 \times 10^{5} \mathrm{BM}$ cells. Cells were incubated with 85 (experiment 1-3) or 25 (experiment 4 ) fmol of ${ }^{125}$ I-sialoadhesin for 1 $\mathrm{h}$ at room temperature, washed, and counted. * $3 \mathrm{D} 6 \mathrm{~F}\left(\mathrm{ab}^{\prime}\right)_{2}$ was added at $50 \mu \mathrm{g} / \mathrm{ml}$ to ${ }^{125} \mathrm{I}$-sialoadhesin $1 \mathrm{~h}$ prior to its addition to cells. ${ }^{\ddagger} 10^{7}$ cells were pretreated in $500 \mu \mathrm{l}$ of PBS with $100 \mathrm{U} / \mathrm{ml} \mathrm{V}$. cholerae or A. ureafaciens sialidase for $60 \mathrm{~min}$ at $37^{\circ} \mathrm{C}$. ${ }^{125} \mathrm{I}$-sialoadhesin was preincubated in $5 \mathrm{mM}$ EDTA for $15 \mathrm{~min}$ prior to addition of RBCs. "Cells were fixed in $0.25 \%$ glutardialdehyde for $10 \mathrm{~min}$ at room temperature, washed, and quenched for $1 \mathrm{~h}$ in PBS containing 1\% BSA prior to the binding assay. ${ }^{125} \mathrm{I}$-sialoadhesin was incubated with Fabs at 2 $\mu \mathrm{g} / \mathrm{ml}$ for $1 \mathrm{~h}$ at $4^{\circ} \mathrm{C}$ prior to addition of cells.

ND, not determined.

from total blood leukocytes by density separation in discontinuous Percoll gradients. Of the five fractions obtained, only the most dense fraction was significantly enriched in neutrophils (63\%) compared with total blood leukocytes (21\% neutrophils). Binding assays were performed to compare the different fractions with total leukocytes and P4 neutrophils (86\% neutrophils) (Fig. $2 b$ ). Binding of sialoadhesin to the neutrophilenriched fraction was at the same level as P4 neutrophils and three- to fourfold higher than the other fractions, whose contents of neutrophils varied from 6 to $24 \%$.

Binding of hemopoietic cells to sialoadhesin expressed by $M \phi$. Peritoneal $M \phi$ cultured for $2-5 \mathrm{~d}$ in $10-20 \%$ mouse serum express high levels of sialoadhesin (17). This provides a useful system to ask whether sialoadhesin expressed on $M \phi$ was able to mediate selective binding of a type similar to that observed with the purified receptor. In initial experiments with BM cells, the overall level of binding varied among experiments as a result of different levels of sialoadhesin expression (compare experiments 1 and 2 in Table III). However, binding of BM cells was sialic acid dependent and did not require the presence of divalent cations (Table III). Binding assays could therefore 


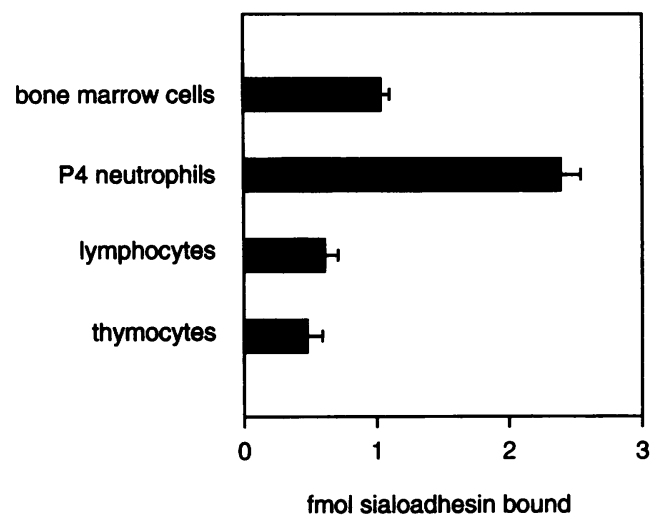

b

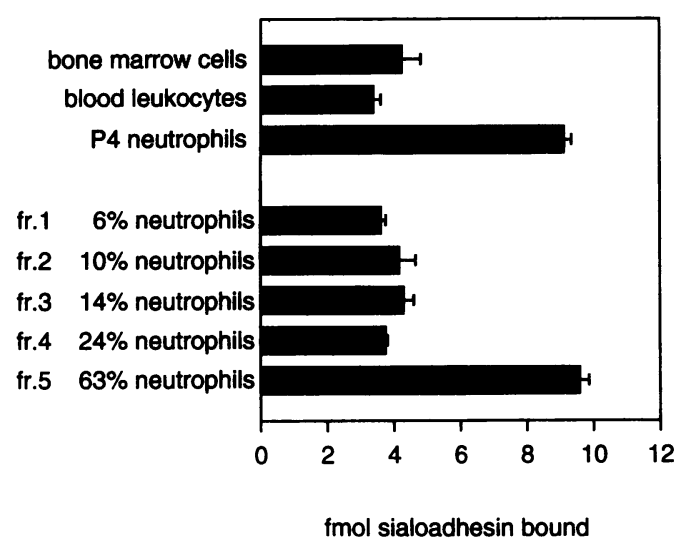

Figure 2. Binding of purified sialoadhesin to different populations of murine cells. 45-fmol $(a)$ or $80-\mathrm{fmol}(b)$ aliquots of ${ }^{125} \mathrm{I}$-sialoadhesin at a specific activity of $120 \mathrm{~Bq} / \mathrm{fmol}(a)$ or $75 \mathrm{~Bq} / \mathrm{fmol}(b)$ were incubated with $5 \times 10^{4}$ cells for $60 \mathrm{~min}$ at $4^{\circ} \mathrm{C}$ and washed. Data shown are means \pm 1 SD of triplicate wells, corrected for nonspecific binding determined with 3D6 $\mathrm{F}\left(\mathrm{ab}^{\prime}\right)_{2}$. Similar results were obtained in two other experiments. In $b$, total blood leukocytes were separated on discontinuous Percoll gradients and different fractions $(f r$.) were compared for binding to ${ }^{125} \mathrm{I}$-sialoadhesin. The percentage of neutrophils in each fraction is shown; in the other populations, the percentages of neutrophils were as follows: blood leukocytes, $21 \%$; P4 neutrophils, $86 \%$.

be performed in the absence of calcium and magnesium, which excluded the contribution of $\mathbf{M} \phi$ adhesion receptors that require divalent cations for function. Direct evidence that the binding of $\mathrm{BM}$ cells to $\mathrm{M} \phi$ was mediated by sialoadhesin, rather than by another co-induced sialic acid-dependent receptor, was demonstrated by the nearly complete inhibition of BM cell binding with Fab or $\mathrm{F}\left(\mathrm{ab}^{\prime}\right)_{2}$ fragments prepared from mAbs 3D6 and IC2 and a rabbit polyclonal antiserum raised to the purified receptor (Fig. 3 and Table III).

Binding assays to $\mathbf{M} \phi$ were then performed with blood leukocytes, P4 neutrophils, lymphocytes isolated from mesenteric lymph nodes, and thymocytes (Fig. 3). In contrast to binding assays with the purified receptor, binding assays with $\mathbf{M} \phi$ resulted in a variable but significant "background" binding that was not inhibitable by 3D6 (Fig. 3). This was most noticeable for P4 neutrophils, thymocytes, and mesenteric lymphocytes and indicates a role for other divalent cation-independent $\mathbf{M} \phi$ adhesion receptors in binding to these cell types.
Table III. Characteristics of BM Cell Binding to Induced M $\phi$ Compared with Sheep RBC Binding

\begin{tabular}{lcc}
\hline \multicolumn{1}{c}{ Treatment } & Sheep RBC & $\begin{array}{c}\text { Murine BM } \\
\text { cells }\end{array}$ \\
\hline & \% Rosettes* & $\begin{array}{c}\text { Cells bound } \\
100 M \phi\end{array}$ \\
Experiment $1^{\ddagger}$ & & \\
Control & $97 \pm 2$ & $525 \pm 80$ \\
1 mM EDTA & $96 \pm 1$ & $496 \pm 105$ \\
5 mM Sialyllactose & $53 \pm 2$ & $11 \pm 4$ \\
10 mM Sialyllactose & $28 \pm 1$ & $12 \pm 1$ \\
20 mM Sialyllactose & $3 \pm 1$ & $6 \pm 3$ \\
Experiment 2 & & \\
Control & $30 \pm 8$ & $124 \pm 22$ \\
$V$. cholerae sialidase & 0 & $22 \pm 12$ \\
Experiment 3" & & \\
Control & ND & $125 \pm 3$ \\
Rab anti-sialoadhesin preimmune IgG & ND & $116 \pm 34$ \\
Rab anti-sialoadhesin immune IgG & ND & $4 \pm 2$ \\
Rab anti-sialoadhesin immune F(ab' ${ }^{\prime}{ }_{2}$ & ND & $4 \pm 3$ \\
Rab anti-sialoadhesin immune Fab & ND & $8 \pm 2$ \\
& & \\
\hline
\end{tabular}

* Binding of $\mathrm{M} \phi$ to sheep RBCs was evaluated as the percentage of $M \phi$ binding more than four sheep RBCs. Data represent mean \pm range values from two (experiments 1 and 2) or three (experiment 3 ) coverslips. At least $200 \mathrm{M} \phi$ were counted per coverslip. ${ }^{\ddagger} \mathrm{M} \phi$ were incubated in EDTA and sialyllactose for $15 \mathrm{~min}$ at $37^{\circ} \mathrm{C}$ prior to addition of cells, and the reagents were maintained throughout the assay. ${ }^{8}$ Cells pretreated in $1 \mathrm{ml}$ of PBS ( $10^{7} \mathrm{BM}$ cells or $0.5 \%$ sheep RBCs) were pretreated with $10 \mathrm{mU}$ of $V$. cholerae sialidase for $60 \mathrm{~min}$ at $37^{\circ} \mathrm{C}$.

" $\mathrm{M} \phi$ were preincubated with antibodies for $15 \mathrm{~min}$ before addition of cells. Preimmune IgG was added at $50 \mu \mathrm{g} / \mathrm{ml}$, and all other immune reagents were at $20 \mu \mathrm{g} / \mathrm{ml}$. ND, not determined; Rab, rabbit.

In three separate experiments, the rank order and relative degree of sialoadhesin-dependent binding for the different cell types was similar to that observed with the soluble receptor. In the experiment shown in Fig. 3, only $35 \%$ of the $\mathrm{M} \phi$ bound more than five sheep RBCs. This low level of expression allowed clear differences in binding among the different cell populations to be seen. Thus, sialoadhesin-dependent binding of neutrophils was 3 times higher than BM cells, 7 times higher than circulating leukocytes, and 15 times higher than mesenteric lymphocytes and thymocytes. In general, binding at the singleM $\phi$ level was heterogeneous and was observed only on the subpopulation of $\mathbf{M} \phi$ that expressed the highest levels of sialoadhesin. This meant that even for low binding cells, like mesenteric lymphocytes and thymocytes, most of the sialoadhesinpositive M $\phi$ bound more than one cell. In all cases, binding of the different cell populations was not accompanied by phagocytosis.

Comparison of cell binding to sialoadhesin and CD22 using recombinant $F c$-adhesins. Through molecular cloning, we have recently shown that sialoadhesin is a type I transmembrane glycoprotein and a new member of the IgSF with 17 extracellular Ig-like domains (3). The amino-terminal four domains share sequence similarity with CD22, a sialic acid-dependent adhesion molecule of B lymphocytes with seven Ig-like domains $(21,22)$. The availability of cDNA clones encoding murine sialoadhesin and CD22 allowed us to compare the binding prop- 


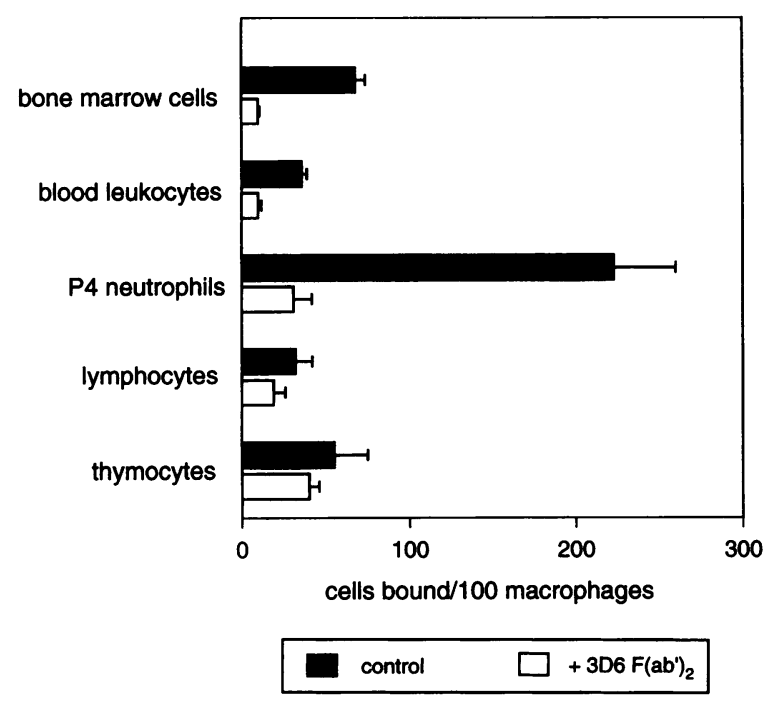

Figure 3. Binding of different murine cell populations to sialoadhesin expressed by $\mathbf{M} \phi$. Resident peritoneal $\mathbf{M} \phi$ were induced to express sialoadhesin by culture for $5 \mathrm{~d}$ in $15 \%$ mouse serum. $2 \times 10^{6}$ cells of each type were allowed to bind for $30 \mathrm{~min}$ at room temperature in divalent cation-free PBS, and nonbound cells were rinsed off. Nonsialoadhesin-mediated binding was assessed in groups of coverslips by preincubation of $\mathrm{M} \phi$ in $50 \mu \mathrm{g} / \mathrm{ml}$ 3D6 $\mathrm{F}\left(\mathrm{ab}^{\prime}\right)_{2}$ for $15 \mathrm{~min}$ before addition of cells. Data represent means +1 SD of triplicate coverlips. In three other experiments a similar rank order of sialoadhesin-dependent binding was observed for each cell type.

erties of both receptors. These experiments were done with recombinant forms of $\mathrm{CD} 22$ and sialoadhesin containing the first three or four extracellular domains, respectively, fused to the Fc portion of human IgG1 (19). In other studies, these truncated $\mathrm{Fc}$-adhesins have been shown to exhibit full sialic acid-dependent binding activity to human RBCs when compared with the respective full-length forms (11).

In initial experiments, ${ }^{125} \mathrm{I}$-labeled $\mathrm{Fc}$-adhesins exhibited no detectable binding activity to cells in fluid-phase binding assays. To increase the avidity of the normally dimeric Fc-adhesins, fluid-phase binding assays were performed using radiolabeled Fc-adhesins that had been precomplexed with an equimolar concentration of anti-human IgG antiserum. This resulted in stable, specific binding to cells that was temperature independent since, similar binding of complexed Fc-sialoadhesin and Fc-CD22 was observed at $4^{\circ} \mathrm{C}$ and room temperature. For all cell types examined (Fig. 4), binding of both Fc-sialoadhesin and Fc-CD22 was sialic acid dependent, but the patterns of cell recognition were distinct. Similarly to the native protein, Fcsialoadhesin bound most strongly to P4 neutrophils, with intermediate binding to BM cells and blood leukocytes, whereas lymphocytes and thymocytes bound poorly. In striking contrast, Fc-CD22 bound most strongly to lymphocytes and blood leukocytes, whereas binding to P4 neutrophils was weak, with intermediate binding to BM cells and thymocytes.

These studies indicate that sialoadhesin binds preferentially to cells of the granulocytic lineage, whereas CD22 shows preference for lymphocytes. To obtain direct evidence for this, we performed cell adhesion assays on plastic wells that had been coated with Fc-adhesins and then characterized the cells that were specifically bound. In this system, binding of cells depended on the coating concentration, with optimal binding being

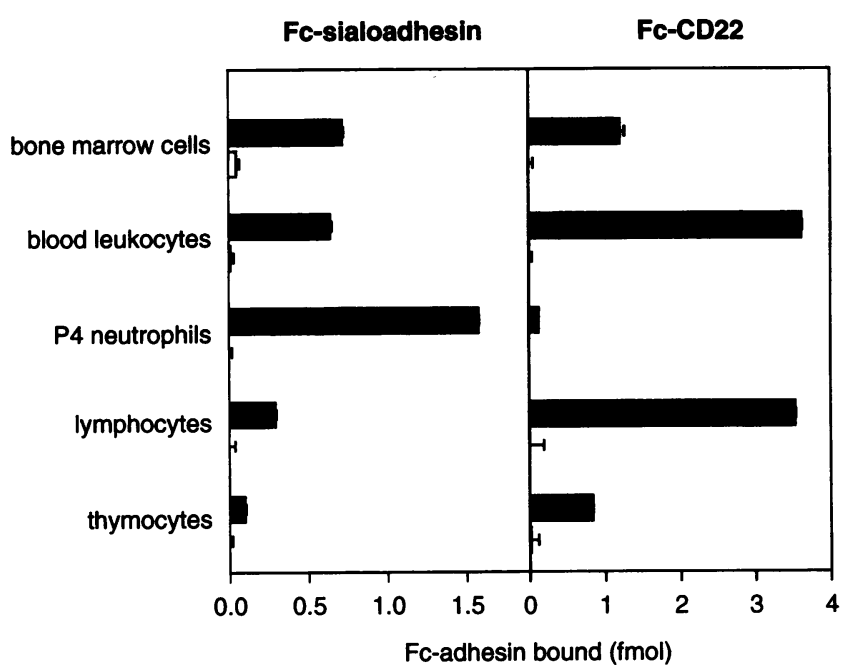

buffer-treated sialidase-treated

Figure 4. Fluid-phase binding assays of complexed, ${ }^{125} \mathrm{I}-\mathrm{Fc}$-sialoadhesin, and ${ }^{125} \mathrm{I}-\mathrm{Fc}-\mathrm{CD} 22$ to different cells. ${ }^{125} \mathrm{I}-\mathrm{Fc}$-adhesins containing the first three (CD22) or four ( sialoadhesin) Ig-like domains, at $2.5 \mathrm{nM}$ and a specific activity of $50 \mathrm{~Bq} / \mathrm{fmol}$, were complexed with an equimolar concentration of goat anti-rabbit IgG (Fc specific), and 20 -fmol aliquots were incubated with $1.5 \times 10^{5}$ glutardialdehyde-fixed cells for $60 \mathrm{~min}$ at room temperature and washed. The sialic acid dependence of binding was determined using sialidase-treated cells under identical conditions. Data shown are means +1 SD of triplicate wells.

observed at around $10 \mathrm{nM}$ Fc-adhesin (Fig. $5 a$ ). No binding was observed with wells coated with Fc-NCAM as a negative control (Fig. $5 a$ ). Binding of cells to Fc-sialoadhesin was sialic acid dependent (data not shown) and inhibited to background levels in the presence of a mixture of $F\left(a b^{\prime}\right)_{2}$ fragments from SER-4 and 3D6 (Fig. $5 b$ ). When the various hemopoietic cell populations were compared, the rank order of binding to Fcsialoadhesin was the same as that observed in all other assays (Fig. $5 b$ ).

For the single-cell analysis, we used BM cells and blood leukocytes since these are complex mixtures of cells that allowed us to determine whether particular subpopulations of cells were selected by Fc-sialoadhesin and Fc-CD22. As shown in Table IV, Fc-sialoadhesin selectively bound to cells of the granulocytic lineage. Thus, blood leukocytes contain $\sim 20 \%$ neutrophils, $70 \%$ lymphocytes, and $5 \%$ monocytes, yet up to $97 \%$ of the cells bound were neutrophils, as defined by the NIMP-R14 $\mathrm{mAb}(16)$ and Giemsa staining. In contrast, CD22 showed a striking preference for lymphocytes. This was most clearly seen with the BM cell suspensions in which $>70 \%$ of the cells bound to Fc-CD22 were developing B lymphocytes as defined by the B220 mAb TIB 146, compared with only $15 \%$ B lymphocytes in the total BM cell suspension (Table IV).

Binding of BM cells to COS cells transfected with sialoadhesin $c D N A$. The single-cell analysis described above was extended to COS cells that had been transfected transiently with a cDNA encoding full-length sialoadhesin. BM cells bound only to the transfected cells, and this was sialic acid dependent and $\mathrm{mAb}$ inhibitable (data not shown). Staining of the bound cells with Giemsa (Fig. $6 a$ ) or by immunoperoxidase labeling with the neutrophil marker NIMP-R14 (Fig. $6 b$ ) showed that the 


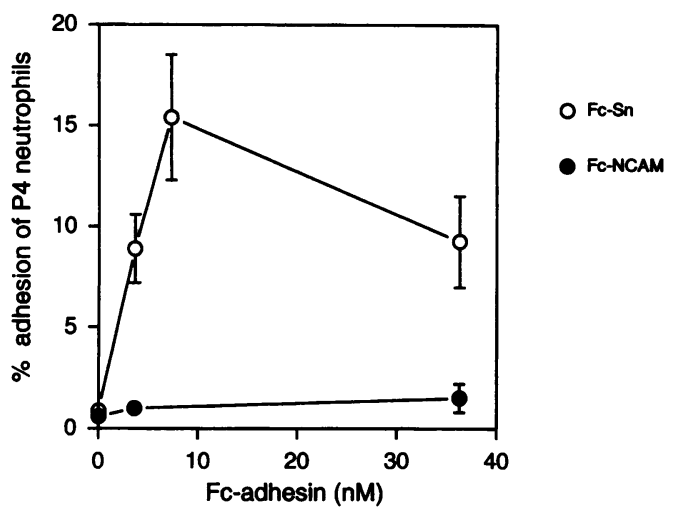

b

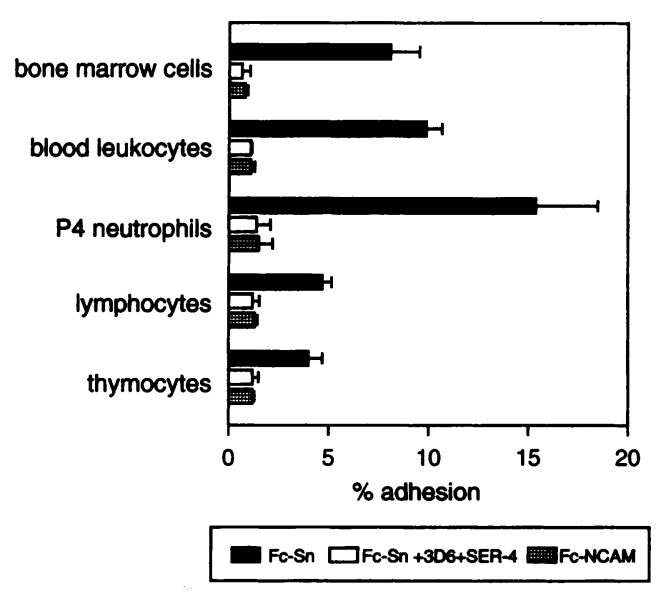

Figure 5. Solid-phase binding assays of Fc-sialoadhesin to different ${ }^{51} \mathrm{Cr}$-labeled cells. In $a$, adhesion assays were performed with $\mathrm{P} 4$ neutrophils to plastic wells coated sequentially with goat anti-human IgG followed by the indicated concentration of $\mathrm{Fc}$-sialoadhesin containing the first four. Ig-like domains. In $b$, various cell types were added to plastic wells coated as previously described, with $\mathrm{Fc}$-sialoadhesin at 10 $\mathrm{nM}$. Specificity of binding in each case was determined in the presence of 3D6 and SER-4 $\mathrm{F}\left(\mathrm{ab}^{\prime}\right)_{2}$ fragments, as well as by plating cells on wells coated with FC-NCAM. Data shown are means \pm 1 SD $(a)$ or means $+1 \mathrm{SD}(b)$ of triplicate wells. Similar results were obtained in three independent experiments.

majority of cells bound were immature cells of the granulocytic lineage.

\section{Discussion}

Here we demonstrate that the $\mathbf{M} \boldsymbol{\phi}$-restricted receptor, sialoadhesin, can function as a selective cellular interaction molecule, with strong preference for cells of the granulocytic lineage. This was observed in a wide range of binding assays using both native and recombinant forms of the receptor, expressed either in the plasma membrane or as purified molecules. In rank order, sialoadhesin bound neutrophils $>$ BM cells $=$ blood leukocytes $>$ lymphocytes $>$ thymocytes.

The oligosaccharide determinants recognized by sialoadhesin, NeuAc $\alpha 2,3 \mathrm{Gal} \beta 1,3 \mathrm{GalNAc}$ and NeuAc $\alpha 2,3 \mathrm{Gal} \beta 1,3(4)-$ GlcNAc, are commonly found on mammalian cells in both glycoproteins and glycolipids. It is therefore important to understand how sialoadhesin can mediate differential binding to di- verse cell types. Similarly to selectin ligands (23), a number of possible mechanisms could influence presentation of the carbohydrate determinants and thereby contribute to selective recognition. These include the nature of the carrier molecules, the effect of ligand clustering, and modification of the sialic acid. Recent studies with murine sialoadhesin (10) and human CD22 (24) have shown that 9-O-acetylation of sialic acid masks recognition. This is likely to be of particular relevance to the cellular interactions mediated by sialoadhesin since murine RBCs contain large amounts of this form of sialic acid (25). M $\phi$ in the BM are in close proximity to both developing RBCs and myeloid cells, but sialoadhesin is concentrated only at the contact sites with myeloid cells (12). It is possible that the presence of 9-O-acetylated sialic acid on RBCs prevents high avidity binding to sialoadhesin. This could also explain why sialoadhesin showed a clear preference for developing myeloid cells over erythroid cells in single-cell analyses of BM cell suspensions.

If the expression of high avidity ligands for sialoadhesin increases in parallel with granulocyte maturation, this raises the interesting question of how differentiating granulocytes are able to dissociate from sialoadhesin expressed on $\mathrm{M} \phi$ in the $\mathrm{BM}$ and enter the blood stream. De-adhesion could be achieved by proteolytic cleavage and shedding of the receptor, as demonstrated for L-selectin (26). Alternatively, de-adhesion may be promoted by the enzymatic removal of sialic acid from the granulocyte surface by extracellular sialidases or by intracellular modification of the sialic acid by $\mathrm{O}$-acetylation or hydroxylation to forms that are not recognized by sialoadhesin (10). Another possibility is that enzymatic modification of either the receptor or the ligand is not required and that detachment results from the enhanced motility of terminally differentiating myeloid cells.

Compared with granulocytes, lymphocyte populations bound very weakly to sialoadhesin in a wide range of binding assays. Previously, a frozen tissue section overlay assay was used to demonstrate that lymphocytes can bind to sialoadhesin expressed by splenic and lymph node $M \phi(13)$. Since the level of binding was dependent on the lymphocyte subset and stage of maturation, this suggests that if sialoadhesin does play a role in lymphocyte interactions, it is likely to be restricted to a discrete subset of these cells. The relatively weak binding of sialoadhesin to lymphocytes is even more apparent if its binding characteristics are compared side by side with CD22, as in the present study. Using recombinant forms of both receptors, CD22 and sialoadhesin exhibited opposite cellular specificities with respect to lymphocytes and granulocytes. At an evolutionary level, this could indicate that the carbohydrate binding specificity of sialoadhesin has become tailored toward interactions with cells of the granulocytic lineage, whereas that of CD22 has become tailored toward interactions with $\mathrm{T}$ and $\mathrm{B}$ lymphocytes.

With respect to mature granulocytes, an important question is whether both resting (circulating) and activated cells bind similarly to sialoadhesin. Using a wide range of binding assays, we failed to see a clear difference between neutrophils obtained from the blood and inflammatory P4 neutrophils. However, we cannot formally exclude the possibility that the circulating neutrophils used in our study were activated during their isolation, although it should be pointed out that the single-cell analyses were performed with blood leukocytes subjected to minimal ex vivo manipulation. In contrast, the P4 neutrophils are likely to consist mostly of activated cells since they had been recruited to an inflammatory site prior to collection. 


\begin{tabular}{|c|c|c|c|c|c|}
\hline \multirow[b]{2}{*}{$\begin{array}{r}\mathrm{mAb} \\
\text { Cells recognized }\end{array}$} & \multicolumn{5}{|c|}{ Percent cells labeled (range)* } \\
\hline & $\begin{array}{c}5 \mathrm{C} 6 \\
\text { Myeloid }\end{array}$ & $\begin{array}{l}\text { NIMP-R14 } \\
\text { Neutrophils }\end{array}$ & $\begin{array}{c}\text { TIB } 146 \\
\text { B lymphocytes }\end{array}$ & $\begin{array}{l}\text { GK1.5 CD4+ } \\
\text { T cells }\end{array}$ & $\begin{array}{c}\text { TIB } 165 \\
\text { CD8 }^{+} \mathrm{T} \text { cells }\end{array}$ \\
\hline \multicolumn{6}{|l|}{ Cell population } \\
\hline Bone marrow, total & $42-49$ & $32-43$ & 16 & ND & ND \\
\hline Bone marrow, adherent to Fc-sialoadhesin ${ }^{\ddagger}$ & $83-85$ & $80-90$ & $5-10$ & ND & ND \\
\hline Bone marrow, adherent to $\mathrm{Fc}-\mathrm{CD} 22^{8}$ & $4-5$ & 2 & $71-80$ & $0-1$ & $1-2$ \\
\hline Blood leukocytes, total & $12-22$ & $10-14$ & 40 & ND & ND \\
\hline Blood leukocytes, adherent to Fc-sialoadhesin & $77-97$ & $88-96$ & $19-26$ & ND & ND \\
\hline Blood leukocytes, adherent to Fc-CD22 & $0-2$ & $1-2$ & $64-78$ & $14-18$ & $7-9$ \\
\hline
\end{tabular}

* Cells were labeled by immunoperoxidase staining with the indicated mAbs. Data show the range of values determined from between one and three independent experiments. For the adherent cells, at least 200 cells were counted in triplicate for each experiment; for the total cell populations, a single preparation was scored for each experiment. ${ }^{\ddagger} \mathrm{Fc}$-sialoadhesin contained the first four amino-terminal Ig-like domains. ${ }^{8} \mathrm{Fc}-\mathrm{CD} 22 \mathrm{contained}$ the first three amino-terminal Ig-like domains. ND, not determined.

In vivo, the adhesion of granulocytes to $\mathrm{M} \phi$ via sialoadhesin could result in a number of possible events relating to their function and turnover. For example, it has been demonstrated that the respiratory burst activity of granulocytes can be suppressed by sialic acid-binding molecules like influenza A hemagglutinin (27) or P-selectin (28). This could be important for preventing undesired tissue damage caused by activated granulocytes. A second consequence of granulocyte binding to $\mathrm{M} \phi$ via sialoadhesin could be to promote engagement of "phagocytic" receptors of the $M \phi$, leading to uptake of the bound cells.

The fate of circulating neutrophils under steady-state conditions is poorly understood, but a proportion of the senescent cells are probably cleared in the circulation by $\mathbf{M} \phi$ of the reticu-
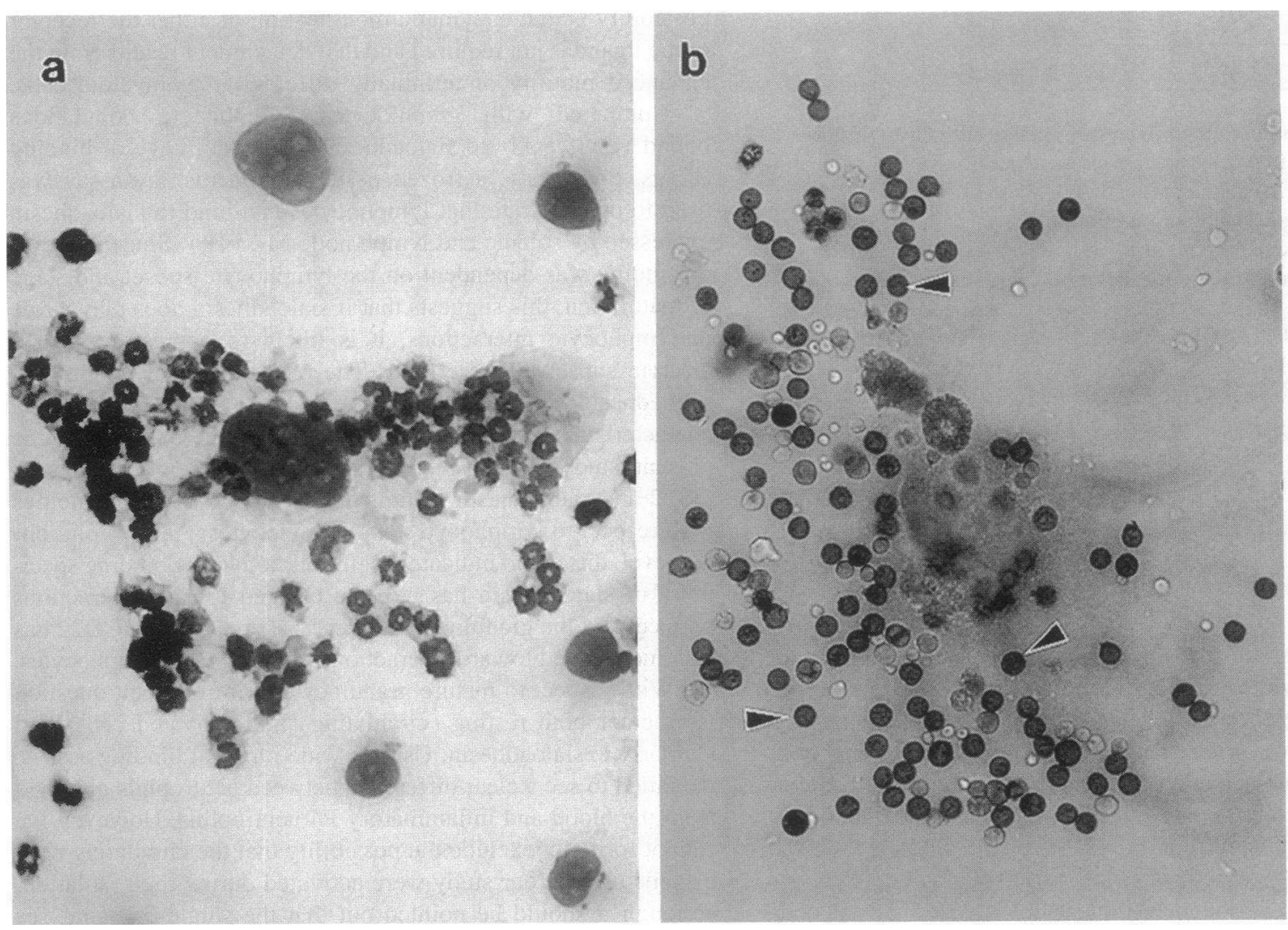

Figure 6. Selective binding of myeloid cells to COS cells expressing sialoadhesin. COS-1 cells were transfected with a cDNA encoding full-length sialoadhesin. $3 \mathrm{~d}$ after transfection, cells were overlaid with $\mathrm{BM}$ cell suspensions for $60 \mathrm{~min}$ at $37^{\circ} \mathrm{C}$. Washed, glutardialdehyde-fixed cells were stained with Giemsa $(a)$ or by immunoperoxidase labeling with the neutrophil-specific mAb NIMP-R14 (b). Arrowheads in $b$ show examples of positively labeled cells. 
loendothelial system while others randomly enter tissues, where they are removed by stromal $\mathbf{M} \phi$. In comparison, the majority of neutrophils recruited to sites of inflammation are thought to be cleared in situ (29). Studies in vivo have demonstrated that sialoadhesin can be induced on $\mathbf{M} \phi$ recruited to a site of inflammation, thereby raising the possibility that the receptor expressed by recruited $\mathbf{M} \phi$ could interact with neutrophils within an inflammatory lesion (30). Neutrophils that enter the afferent lymphatics of draining lymph nodes (31) would encounter a dense network of sialoadhesin-positive stromal $\mathbf{M} \phi$ within the subcapsular sinus (14). Initial binding events mediated by sialoadhesin could promote ligation of phagocytic receptors with corresponding ligands on the neutrophil and result in a more efficient uptake process. Recent studies have shown that at least two $M \phi$ receptors, CD36 and the vitronectin receptor, are important for mediating the uptake of apoptotic neutrophils in vitro $(32,33)$. Cooperativity between sialoadhesin and other receptors in clearance of neutrophils would be analogous to the coordinated interaction of endothelial cell and neutrophil adhesion receptors during neutrophil margination and extravasation in acute inflammation (reviewed by Butcher [34]).

In conclusion, our study demonstrates that cell type-specific glycosylation of hemopoietic cells results in selective interactions of developing and mature granulocytes with sialoadhesin expressed by $\mathbf{M} \phi$. Importantly, the highly restricted expression pattern of sialoadhesin would limit these cellular interactions to $\mathbf{M} \phi$ populations within hemopoietic and secondary lymphoid tissues and possibly at sites of inflammation.

\section{Acknowledgments}

We thank Dr. Geneviève Milon and Professor Roland Schauer for enthusiastic support, Dr. Gordon MacPherson for performing the intrasplenic injection, and Peter Tree for help with preparation of P4 neutrophils.

This work was supported by grants from the Association de Recherche pour le Cancer (ARC 6369), the Medical Research Council, UK, a Collaborative Research Grant from the North Atlantic Treaty Organisation, and a grant from the Mizutani Foundation for Glycoscience.

\section{References}

1. Varki, A. 1992. Selectins and other mammalian sialic acid binding lectins. Curr. Opin. Cell Biol. 4:257-266.

2. Horstkorte, R., M. Schachner, J. P. Magyar, T. Vorherr, and B. Schmitz. 1993. The 4th immunoglobulin-like domain of NCAM contains a carbohydraterecognition domain for oligomannosidic glycans implicated in association with L1 and neurite outgrowth. J. Cell Biol. 121:1409-1421.

3. Crocker, P. R., S. Mucklow, V. Bouckson, A. McWilliam, A. C. Willis, S. Gordon, G. Milon, S. Kelm, and P. Bradfield. 1994. Sialoadhesin, a macrophage sialic acid-binding receptor for haemopoietic cells with 17 immunoglobulin-like domains. EMBO J. 13:4490-4503.

4. Sgroi, D., A. Varki, S. Braesch-Anderson, and I. Stamenkovic. 1993. CD22, a B cell-specific immunoglobulin superfamily member is a sialic acid-binding lectin. J. Biol. Chem. 268:7011-7018.

5. Powell, L. D., D. Sgroi, E. R. Sjoberg, I. Stamenkovic, and A. Varki. 1993. Natural ligands of the B cell adhesion molecule $\mathrm{CD} 22 \beta$ carry $\mathrm{N}$-linked oligosaccharides with $\alpha-2,6$-linked sialic acids that are required for recognition. J. Biol. Chem. 268:7019-7027.

6. Engel, P., Y. Nojima, D. Rothstein, L.-J. Zhou, G. L. Wilson, J. H. Kehrl, and T. F. Tedder. 1993. The same epitope on CD22 of B lymphocytes mediates the adhesion of erythrocytes, $\mathrm{T}$ and $\mathrm{B}$ lymphocytes, neutrophils and monocytes. J. Immunol. 150:4719-4732.

7. Powell, L. D., and A. Varki. 1994. The oligosaccharide binding specificities of CD22-beta, a sialic acid-specific lectin of B-cells. J. Biol. Chem. 269:1062810636.

8. Aruffo, A., S. B. Kanner, D. Sgroi, J. A. Ledbetter, and I. Stamenkovic. 1992. CD22-mediated stimulation of T-cells regulates T-cell receptor CD3-induced signaling. Proc. Natl. Acad. Sci. USA. 89:10242-10246.
9. Crocker, P. R., S. Kelm, C. Dubois, B. Martin, A. S. McWilliam, D. M. Shotton, J. C. Paulson, and S. Gordon. 1991. Purification and properties of sialoadhesin, a sialic acid-binding receptor of murine tissue macrophages. EMBO J. 10:1661-1669.

10. Kelm, S., R. Schauer, J.-C. Manuguerra, H.-J. Gross, and P. R. Crocker. 1994. Modifications of cell surface sialic acids modulate cell adhesion mediated by sialoadhesin and CD22. Glycoconj. J. 11:541-549.

11. Kelm, S., A. Pelz, R. Schauer, M. Filbin, S. Tang, M.-E. D. Bellard, R. Schnaar, J. Mahoney, A. Hartnell, P. Bradfield, and P. Crocker. 1994. Sialoadhesin, MAG and CD22 define a new family of sialic acid-dependent adhesion molecules of the immunoglobulin superfamily. Curr. Biol. 4:965-972.

12. Crocker, P. R., Z. Werb, S. Gordon, and D. F. Bainton. 1990. Ultrastructural localisation of a macrophage-restricted sialic acid binding hemagglutinin, SER, in macrophage-hemopoietic cell clusters. Blood. 76:1131-1138.

13. Van den Berg, T. K., J. P. Breve, J. G. M. C. Damoiseaux, E. A. Dopp, S. Kelm, P. R. Crocker, C. D. Dijkstra, and G. Kraal. 1992. Sialoadhesin on macrophages: its identification as a lymphocyte adhesion molecule. J. Exp. Med. 176:647-655.

14. Crocker, P. R., and S. Gordon. 1989. Mouse macrophage hemagglutinin (sheep erythrocyte receptor) with specificity for sialylated glycoconjugates characterised by a monoclonal antibody. J. Exp. Med. 169:1333-1346.

15. Rosen, H., and S. Gordon. 1987. Monoclonal antibody to the murine type 3 complement receptor inhibits adhesion of myelomonocytic cells in vitro and inflammatory cell recruitment in vivo. J. Exp. Med. 169:1685-1701.

16. Lopez, A. F., M. Strath, and C. J. Sanderson. 1984. Differentiation antigens of mouse eosinophils and neutrophils identified by monoclonal antibodies. Br. J. Haematol. 57:489-494.

17. Crocker, P. R., M. Hill, and S. Gordon. 1988. Regulation of a murine macrophage haemagglutinin (sheep erythrocyte receptor) by a species-restricted serum factor. Immunology. 65:515-522.

18. Fauve, R. M., H. Jusforgues, and B. Hevin. 1983. Maintenance of granuloma macrophages in serum-free medium. J. Immunol. Methods. 64:345-348.

19. Simmons, D. L. 1993. Cloning cell surface molecules by transient expression. In: Cellular interactions in development. A Practical Approach. D. A. Hartley, editor. IRL Press, Oxford. 93-128.

20. Crocker, P. R., and S. Gordon. 1986. Properties and distribution of a lectin-like hemagglutinin differentially expressed by stromal tissue macrophages. J. Exp. Med. 164:1862-1875.

21. Wilson, G. L., C. H. Fox, A. S. Fauci, and J. H. Kehrl. 1991. cDNA cloning of the B cell membrane protein CD22: a mediator of B-B cell interactions. J. Exp. Med. 173:137-146.

22. Torres, R. M., C. L. Law, L. Santosargumedo, P. A. Kirkham, K. Grabstein, R. Parkhouse, and E. A. Clark. 1992. Identification and characterization of the murine homolog of CD22, a lymphocyte-B-restricted adhesion molecule. J. Immunol. 149:2641-2649. 7397.

23. Varki, A. 1994. Selectin ligands. Proc. Natl. Acad. Sci. USA. 91:7390-

24. Sjoberg, E., L. Powell, A. Klein, and A. Varki. 1994. Natural ligands of the $\mathrm{B}$ cell adhesion molecule CD22 $\beta$ can be masked by $9-\mathrm{O}$-acetylation of sialic acids. J. Cell Biol. 126:549-562.

25. Klotz, F. W., P. A. Orlandi, G. Reuter, S. J. Cohen, J. D. Haynes, R. Schauer, R. J. Howard, P. Palese, and L. H. Miller. 1992. Binding of Plasmodium falciparum 175-kilodalton erythrocyte binding antigen and invasion of murine erythrocytes requires $\mathrm{N}$-acetylneuraminic acid but not its acetylated form. $\mathrm{Mol}$. Biochem. Parasitol. 51:49-54.

26. Kishimoto, T. K., M. A. Jutila, and E. C. Butcher. 1990. Identification of a human peripheral lymph node homing receptor: a rapidly down-regulated adhesion molecule. Proc. Natl. Acad. Sci. USA. 87:2244-2248.

27. Cassidy, L. F., D. S. Lyles, and J. S. Abramson. 1989. Depression of polymorphonuclear leukocyte functions by purified influenza virus hemagglutinin and sialic acid binding lectins. J. Immunol. 142:4401-4406.

28. Wong, C. S., J. R. Gamble, M. P. Skinner, C. M. Lucas, M. C. Berndt, and M. A. Vadas. 1991. Adhesion protein GMP140 inhibits superoxide anion release by human neutrophils. Proc. Natl. Acad. Sci. USA. 88:2397-2401.

29. Florey, H. W. 1962. Chemotaxis, phagocytosis and the formation of abscesses. In General Pathology. H. W. Florey, editor. Lloyd-Luke (Medical Books) Ltd., London. 98-127.

30. Perry, V. H., P. R. Crocker, and S. Gordon. 1992. The blood-brain barrier regulates the expression of a macrophage sialic acid binding receptor on microglia. J. Cell Sci. 101:201-207.

31. Yoffey, J. M., and F. C. Courtice. 1970. Structure and function of lymph nodes. In Lymphatics, Lymph and the Lymphomyeloid Complex. J. M. Yoffey and F. C. Courtice, editors. Academic Press Inc., London/New York. 517-619.

32. Savill, J., I. Dransfield, N. Hogg, and C. Haslett. 1990. Vitronectin receptor-mediated phagocytosis of cells undergoing apoptosis. Nature (Lond.). 343:171-173.

33. Savill, J., N. Hogg, Y. Ren, and C. Haslett. 1992. Thrombospondin cooperates with CD36 and the vitronectin receptor in macrophage recognition of neutrophils undergoing apoptosis. J. Clin. Invest. 90:1513-1522.

34. Butcher, E. C. 1991. Leukocyte-endothelial cell recognition - 3 (or more) steps to specificity and diversity. Cell. 67:1033-1036. 